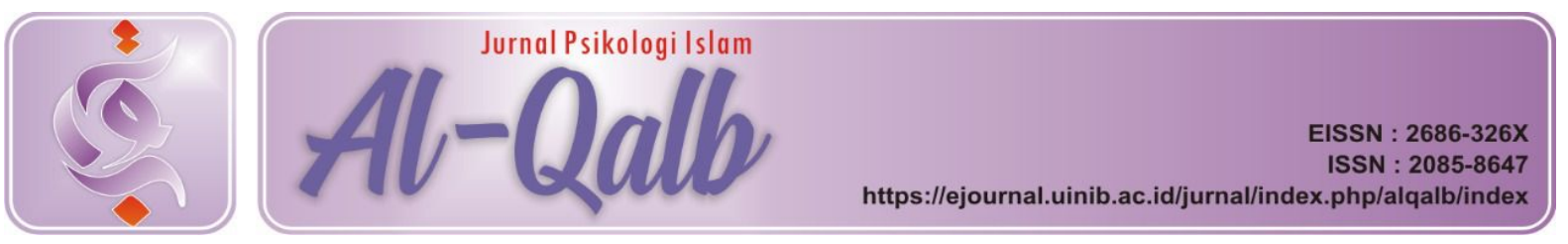

\title{
PENGARUH MEMBACA AL-QUR'AN TERHADAP PENINGKATAN ADVERSITY QUOTIENT PADA SISWI ASRAMA SITI KHADIJAH
}

Received: $20^{\text {th }}$ September 2018; Revised: 06 $6^{\text {th }}$ October 2018; Accepted: $22^{\text {th }}$ November 2018

\section{Murisal}

UIN Imam Bonjol Padang

Email: murisal@uinib.ac.id

Dian Arianti

UIN Imam Bonjol Padang

Email: dhyanarianti@gmail.com
ABSTRACT. Al-Qur'an which was revealed to change the thoughts, attitudes and human behavior and pointed at them. So that humans can avoid the downturn in the face of life problems. Each individual has a different response to the problem it faces. Some choose to avoid problems and some struggle to resolve the issue. This is seen from the toughness or the individual's Adveristy Quotient. Adversity Quotient is one form of intelligence that underlies one's success in facing a challenge in the event of difficulty or failure. In this case reading the Qur'an that is reflected to the teenager to get motivation and understanding of his views on the problems they face. As well as through reading the Qur'an will contribute to the improvement of adolescent Adversity Quotient.

The research method used is pure experimental method, with pretest-posttest control group design design with 38 subjects. Subjects were selected based on randomization measured using Adveristy Quotient scale, divided into two groups: the experimental group and the control group, each group was 19 people. The experimental group was given the treatment of reading al-Qur'an, while the control group did not. Based on the pretest results, the experimental group and the control group showed moderate category Adversity Quotient. In the posttest results, the experimental group experienced improvement after treatment. While the untreated control group did not increase, even the decrease of Adversity Quotient

The result of the research proves that the giving of treatment in reading al-Qur'an has an effect on the increase of Adversity Quotient to the students of hostel Siti Khadijah MAN Koto Baru Solok. Adversity Quotient scale proves that the implementation of reading al-Qur'an takes place smoothly for the participants.

Keywords: Adversity Quotient, Reading al-Qur'an, Teenagers

\section{A. PENDAHULUAN}

Al-Qur'an secara etimologi diambil

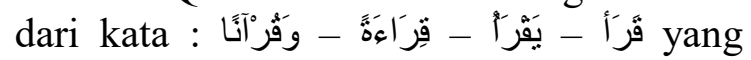

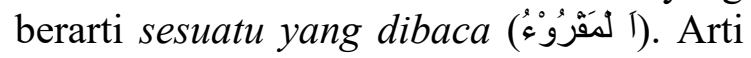
ini menyiratkan anjuran kepada umat Islam untuk membaca al-Qur'an. Al-Qur'an juga membentuk mashdar dari القِرَاءَهُ yang berarti menghimpun dan mengumpulkan (الضَّمُ وَالجَمْعُ) (Anshori, 2013). Membaca al-
Qur'an adalah membaca kitab suci yang diturunkan Allah SWT kepada Nabi Muhammad SAW dengan aktivitas melafalkan, menelaah dan mempelajarinya sebagai pedoman hidup dalam kehidupan sehari-hari.

Al-Qur'an memuat pokok-pokok ajaran yang mengarahkan manusia untuk menjadi pribadi yang lebih baik. Selain 
berfungsi sebagai petunjuk dan bimbingan, al-Qur'an juga berfungsi sebagai pembeda yang hak dan yang bathil, juga sebagai penjelas terhadap segala sesuatu, akhlak, moralitas dan etikaetika yang patut dipraktekkan dalam kehidupan sehari-hari (Nawawi, 2011). Penerapan semua perintah Allah SWT itu akan memberikan dampak positif bagi pribadi individu itu sendiri. Oleh karena itu, umat Islam perlu memahami pedoman agama Islam, salah satunya al-Qur'an. Pemahaman terhadap kandungan al-Qur'an dan mengamalkannya dalam kehidupan sehari-hari secara konsisten. Hal ini dapat terlaksana apabila individu telah membaca, memahami dan mengamalkan al-Qur'an.

Syaik As-Sayyid Al-Maliki (dalam Khon, 2011) menjelaskan keutamaan membaca al-Qur'an secara singkat sebagai berikut: Menjadi keluarga Allah SWT dan pilihan-Nya; Orang yang mahir membaca al-Qur'an tingkatannya bersama para Malaikat; Al-Qur'an sebagai hidangan Allah SWT, barang siapa yang memasukinya maka dia akan aman; Rumah yang dibacakan al-Qur'an dihadiri para Malaikat dan menjadi leluasa bagi penghuninya; Rumah yang dibacakan alQur'an terpencar langit hingga ke penduduk langit; Membaca al-Qur'an akan menjadikan begitu banyak kebaikan dan keberkahan; Membaca al-Qur'an akan memperindah pembacanya; Membaca alQur'an adalah penerang bagi hati; Membaca al-Qur'an sangat bermanfaat bagi pembacanya dan orangtuanya; Pembaca al-Qur'an tidak akan terkena bencana di hari kiamat kelak; Al-Qur'an memberi syafa'at bagi pembacanya; Bacaan al-Qur'an mengharumkan pendengarnya dengan minyak dan misik (minyak kasturi).

Langkah awal dalam memperoleh dan memahami semua petunjuk dalam alQur'an adalah dengan kegiatan membaca. Rasulullah SAW menasihatkan agar membaca al-Qur'an. Beliau menjanjikan pahala dan balasan yang besar dengan membacanya itu, yaitu berupa ketenteraman hati, ketajaman logika dan tercerahkannya hati (Pedak, 2009). AlQur'an mempunyai pengaruh yang sangat kuat terhadap jiwa manusia secara umum yang akan mampu menggerakkan jiwa manusia. Melalui kegiatan membaca alQur'an berpengaruh terhadap sikap-sikap positif karena ketika membaca al-Qur'an diibaratkan berkomunikasi langsung dengan Allah SWT sehingga dapat memberikan ketenangan jiwa yang bersifat rohani. Dengan demikian ketika seseorang memiliki permasalahan mereka mampu menyelesaikan dengan kepala dingin yaitu sabar, sadar, rendah hati dan yang paling utama adalah selalu mengingat kehadiran Allah SWT (Zulaiha, 2014).

Muhammad Utsman Najati (2005) juga berpendapat bahwa al-Qur'an diturunkan untuk mengubah pikiran, sikap dan perilaku manusia, serta menunjuki mereka. Al-Qur'an telah berhasil untuk membentuk kepribadian yang utuh dan sempurna. Sehingga manusia bisa terhindar dari keterpurukannya dalam menghadapi permasalahan atau musibah dalam hidup. Musibah merupakan pengalaman yang dirasakan tidak menyenangkan karena dianggap merugikan oleh korban yang terkena musibah (Jalaluddin, 2011). Musibah dapat menimbulkan penderitaan maupun kesengsaraan bagi korban yang berlangsung dalam waktu yang panjang atau bahkan seumur hidup. Kondisi ini dapat menyebabkan manusia mengalami ketertekanan dalam menjalani kehidupan di dunia ini sehingga menjadi beban yang cukup berat dirasakan.

Peran agama juga membutuh-kan faktor pendukung seseorang dalam menghadapi musibah yang dialaminya diantaranya adalah daya tahan seseorang dalam menghadapi tekanan baik dari dalam diri maupun dari lingkungan. Outlette dan Warner mengatakan bahwa sifat daya tahan adalah predictor dan kualitas hidup secara keseluruhan (Sapuri, 2009). Seseorang yang memiliki daya tahan yang tinggi akan lebih mampu bertahan dalam 
menghadapi situasi yang tidak menyenangkan atau menyakitkan.

Setiap kesulitan merupakan suatu tantangan dan setiap tantangan merupakan suatu peluang, yaitu suatu peluang untuk melakukan suatu perubahan untuk menjadi lebih baik dari sebelumnya. Namun, pada umumnya kebanyakan orang berhenti berusaha atau menyerah sebelum tenaga, batas kemampuan dan potensinya benarbenar telah digunakan untuk menghadapi tantangan-tantangan di dalam dirinya. Akan tetapi dengan adanya Adveristy Quotient yang baik pada diri individu. Hal tersebut akan membuat individu tersebut mampu untuk bertahan menghadapi kesulitan dan mengatasinya.

Menurut Chaplin (2009) dalam kamus psikologi, intelligence atau quotient berarti cerdas dan pandai. Sedangkan dalam kamus bahasa Inggris-Indonesia, kata "adversity" diartikan dengan kesengsaraan dan kemalangan (Echols \& Shadily, 2014). Secara ringkas Stoltz mendefenisikan Adversity Quotient sebagai kecerdasan yang dimiliki seseorang dalam menghadapi kesulitan, hambatan dan mampu untuk mengatasinya. Adversity Quotient merupakan sikap menginternalisasi keyakinan. Adversity Quotient juga merupakan kemampuan individu untuk menggerakkan tujuan hidup ke depan dan juga sebagai pengukuran tentang bagaimana seseorang berespon terhadap kesulitan (Stoltz, 2000).

Menurut Stoltz (2000) Adversity Quotient memiliki empat dimensi yang biasa disingkat dengan CO2RE yaitu: control, origin dan ownership, reach dan endurance. Berdasarkan dimensi-dimensi Adversity Quotient ini terdapat tipe-tipe manusia yang bisa menggambarkan kemampuan Adversity Quotient. Stoltz membagi tipe-tipe manusia ini dengan menggambarkan orang yang sedang melakukan pendakian gunung, yaitu berhenti (quitters), berkemah (champers) dan pendaki (climbers). Adapun faktor yang dapat mempengaruhi Adversity Quotient seseorang antara lain bakat, kemauan, kecerdasan, kesehatan, karakteristik kepribadian, genetika, pendidikan dan keyakinan.

Sebagai umat Islam dalam menghadapi permasalahan hidup tentunya akan mengadu kepada Allah SWT yang bisa dilakukan dalam bentuk berdoa, shalat maupun membaca al-Qur'an. Hal ini apabila dilakukan setidaknya dapat mengurangi sedikit beban yang dirasakan karena masalah tersebut datangnya dari Allah SWT. Terlebih Pelajar yang belajar di sekolah agama masih berada di usia remaja atau adolescence dimana masa remaja merupakan suatu masa dimana ketegangan emosi meninggi sebagai akibat dari perubahan fisik dan kelenjar (Hurlock, 1993), tentunya memiliki ilmu pengetahuan tentang agama lebih daripada remaja yang bersekolah di sekolah umum. Terlebih apabila sekolah memiliki asrama, di mana pelajarannya memiliki nilai lebih dengan belajar ilmu agama terlebih mereka melakukan kegiatan membaca al-Qur'an lebih rutin yang seharusnya dapat menghasilnya pelajar yang memiliki daya tahan tinggi terhadap musibah yang dialaminya.

Namun, menjalani pendidikan di asrama tentu sangat berbeda dengan pendidikan di luar asrama. Segala aktivitas belajar dan kehidupan sehari-hari dilakukan di dalam asrama. Hal ini menarik peneliti mengingat siswi yang tinggal di asrama adalah remaja yang berada pada fase transisi yang penuh dengan gejolak dalam kehidupan pribadi dan sosialnya. Monks dkk (1994) mengatakan masa transisi terjadi sebagai akibat dari banyaknya perubahan pada kontekstual yang terjadi secara bersamaan di keluarga, sekolah dan konteks lainnya. Pada masa transisi ini, status remaja tidak jelas dan terdapat keraguan peran yang akan dilakukan. Pada masa ini seorang remaja mencari identitas diri yang tidak jarang dalam prosesnya menimbulkan krisis badai dan topan (storm and stress) dalam kehidupan emosinya (Mar'ati dan Chaer, 2016). 
Hal ini ditambah dengan kehidupan sekarang yang perkembangan zaman semakin maju dan berkembang, berbagai permasalahan, hambatan, kesulitan serta rintangan dalam hidup ini semakin banyak. Dalam teknologi informasi terjadi banyak kemajuan yang pesat, hal tersebut menimbulkan beban berjuang dalam diri remaja sendiri dan beban untuk menyerap informasi yang tingkatnya semakin tinggi telah membuat kewalahan sebagian besar masyarakat terutama remaja. Akibatnya yang sering terjadi adalah sutu perasaan putus asa, pesimis, kegelisahan serta kecemasan yang semakin meluas (Stoltz, 2000).

Seorang pelajar yang mendapatkan kesusahan, hendaknya berdoa untuk memperkuat keyakinannya (Sapuri, 2009). Dalam hal ini selain berdoa pelajar juga bisa membaca al-Qur'an untuk menambah keyakinannya kepada Allah SWT dengan melaksanakan ibadah-ibadah lainnya. Membaca al-Qur'an yang direfleksikan dalam diri remaja secara berulang-ulang. Hal ini diharapkan dapat memberikan motivasi dan pemahaman dari membacanya, dalam hal ini para remaja mengenai pandangannya terhadap masalah yang mereka hadapi. Diharapkan mereka dapat meneguhkan pegangan hidupnya. Ketika sudah membaca al-Qur'an maka mereka dapat mengembalikan semua hal yang terjadi dalam hidupnya ke dalam ketentuan Allah SWT. Mereka juga tidak lagi merasa berputus asa, memahami janji dan ketentuan Allah SWT dalam al-Qur'an yang mereka baca. Saat sekarang ini telah banyak remaja yang jarang membaca alQur'an, padahal melalui kegiatan ini remaja bisa mengetahui bagaimana sikap dan perilaku yang seharusnya dalam menghadapi kesulitan-kesulitan serta memiliki pegangan hidup yang kuat.

\section{B. METODE}

Desain eksperimen yang peniliti gunakan adalah jenis desain eksperimen ulang (pretest-posttest control group design) dengan kelompok kontrol sebagai pembanding dari hasil perlakuan kepada kelompok eksperimen (Latipun, 2006).

Identivikasi variabel penelitian yaitu variabel eksperimental (variabel bebas) pada penelitian ini adalah membaca alQur'an dan variabel terikat dalam penelitian ini adalah Adversity Quotient. Subjek Penelitian dalam penelitian ini adalah siswi asrama Siti Khadijah MAN Koto Baru Solok, Mampu membaca alQur'an dan berada pada usia remaja pubertas (14-18 tahun) dengan jumlah sebanyak 38 siswi, dengan teknik pengambilan sampel yaitu sampling jenuh yaitu teknik penentuan sampel bila semua anggota populasi digunakan sebagai sampel (Sugiyono, 2010).

Langkah-langkah persiapan dan pelaksanaan prosedur eksperimen diawali dengan mempersiapkan skala Adversity Quotient untuk diuji cobakan. Penelitian diawali screening untuk mendapatkan calon subjek penelitian. Data yang diperoleh dari screening sekaligus berguna sebagai data skor pretest subjek yang terpilih. Setelah dilakukan tes awal, kemudian perlakuan yang diberikan kepada kelompok eksperimen yaitu membaca al-Qur'an, sedangkan kelompok kontrol tidak diberikan perlakuan. Setelah perlakuan diberikan selama tujuh hari, kemudian kedua kelompok diberikan posttest.

\section{HASIL PENELITIAN}

Berdasarkan analisis kuantitatif dapat diketahui tingkat signifikansi sebesar 0,000, dikarenakan tingkat signifikansi lebih kecil dari tingkat kesalahan $(0,000>0,05)$ dengan kata lain terdapat perbedaan tingkat Adversity Quotient antara kelompok eksperimen dengan kelompok kontrol. Dimana pada kelompok eksperimen ratarata peningkatan tingkat Adversity Quotient yaitu 29,00, sedangkan pada kelompok kontrol peningkatan tingkat Adversity Quotient nya adalah 10,00.

Berdasarkan hasil tersebut, dapat disimpulkan bahwa terdapat perbedaan peningkatan Adversity Quotient siswi 
Asrama Siti Khadijah yang signifikan setelah melakukan kegiatan membaca alQur'an. Dari hasil analisis kuantitatif dapat disimpulkan bahwa hipotesis penelitian ini diterima, yaitu membaca al-Qur'an dapat meningkatkan Adversity Quotient siswi asrama.

Sementara itu, hasil uji Uji Friedman Kelompok Ekperimen dan Kontrol

a) Uji Friedman Kelompok Eksperimen

Pada hipotesis yang dirumuskan oleh peneliti bahwa terdapat peningkatan Adversity Quotient siswi Asrama Siti Khadijah MAN Koto Baru Solok antara skor pretest dengan posttest pada kelompok eksperimen. Hasil analisis yang dilakukan menunjukkan tingkat signifikansi sebesar 0,000. Dikarenakan tingkat signifikansi lebih kecil dari tingkat kesalahan $(0,000<0,005)$ maka hipotesis diterima. Dengan kata lain terdapat perbedaan peningkatan tingkat Adversity Quotient siswi Asrama Siti Khadijag MAN Koto Baru Soloksetelah diberikan treatment berupa membaca al-Qur'an. Kemudian dapat diketahui bahwa tingkat motivasi kerja kelompok eksperimen meningkat, dimana pretest menunjukkan mean rank sebesar 1,00, kemudian meningkat pada posttest sebesar 2,00.

b) Uji Friedman Kelompok Kontrol

Pada hipotesis yang dirumuskan oleh peneliti bahwa tidak terdapat peningkatan Adversity Quotient siswi Asrama Siti Khadijah MAN Koto Baru Solok antara skor pretest dengan posttest pada kelompok kontrol. Hipotesis akan ditolak jika tingkat signifikan lebih kecil dari tingkat kesalahan dengan nilai 0,05 . Hasil analisis yang dilakukan menunjukkan tingkat signifikansi sebesar 0,059. Dikarenakan tingkat signifikansi lebih besar dari tingkat kesalahan $(0,059>0,05)$ maka hipotesis diterima. Dengan kata lain tidak terdapat peningkatan Adversity Quotient siswi Asrama Siti Khadijah MAN Koto Baru Solok. Kemudian dapat diketahui bahwa tingkat motivasi kerja kelompok kontrol tidak mengalami peningkatan, dimana pretest menunjukkan mean rank sebesar 1,71, kemudian menurun pada posttest sebesar 1,29.

Perbedaan uji Friedman antara kelompok eksperimen dan kelompok kontrol dapat diketahui dari gambar berikut:

\section{Perbandiangan Gain Score antara \\ Kelompok Eksperimen dan Kontrol}

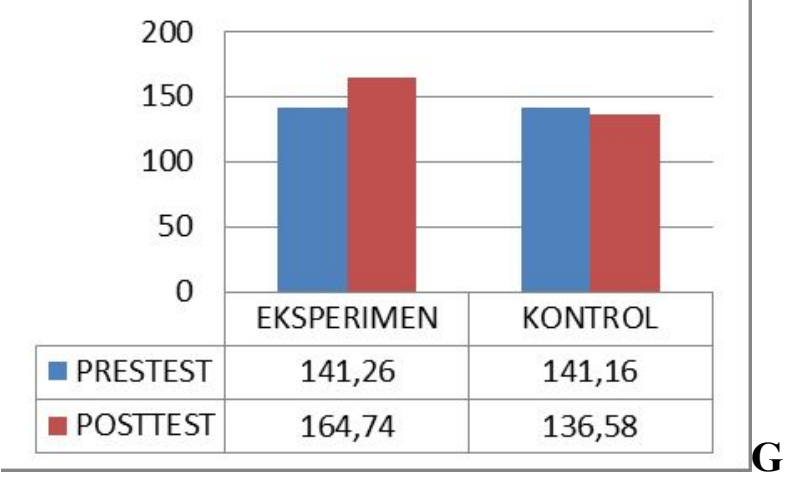

ambar 1

Gambar di atas menunjukkan adanya peningkatan skor rata-rata dari Adversity Quotient dengan melakukan kegiatan membaca al-Qur'an pada pretest dan posttets, kelompok eksperimen dan kelompok kontrol. Pada kelompok eksperimen menunjukkan mean score prestest sebesar 141,26 dan pada posttest 164,74 . Sedangkan pada kelompok kontrol menunjukkan mean score pretest sebesar 141,26 dan pada posttest 136,58.

\section{PEMBAHASAN}

Permasalahan atau musibah yang dialami oleh seseorang merupakan pengalaman yang dirasakan tidak menyenangkan karena dianggap merugikan oleh korban yang terkena masalah. Permasalahan dapat menimbulkan penderitaan maupun kesengsaraan bagi korban terkadang berlangsung dalam waktu yang panjang. Kondisi ini dapat menyebabkan individu mengalamo ketertekanan, keputusasaan dalam menjalani kehidupan di dunia ini sehingga menjadi beban yang cukup berat dirasakan.

Peran agama juga membutuhkan faktor pendukung diantaranya daya tahan seseorang dalam menghadapi tekanan baik dari dalam diri maupun lingkungan, hal ini bisa diatasi dengan salah satunya adalah 
membaca al-Qur'an. Outlette dan Warner mengatakan bahwa sifat daya tahan adalah prediktor dari kualitas hidup secara keseluruhan (Sapuri, 2009). Seseorang yang memiliki daya tahan yang tinggi akan lebih mampu bertahan dalam menghadapi situasi yang tidak menyenangkan atau menyakitkan.

Menurut Sapuri (2009) Adversity Quotient dapat disebut dengan kecerdasan adversitas atau kecerdasan mengubah kesulitan, tantangan dan hambatan menjadi sebuah peluang yang besar. AQ adalah pengetahuan baru untuk memahami dan meningkatkan kesuksesan. AQ adalah tolak ukur untuk mengetahui kadar respon terhadap kesulitan dan merupakan peralatan praktis untuk memperbaiki respon-respon terhadap kesulitan.

Secara ringkas Stoltz (2000) mendefenisikan Adversity Quotient sebagai kecerdasan yang dimiliki seseorang dalam menghadapi kesulitan, hambatan dan mampu untuk mengatasinya. Adversity Quotient merupakan sikap menginternalisasi keyakinan. Adversity Quotient juga merupakan kemampuan individu untuk menggerakkan tujuan hidup ke depan dan juga sebagai pengukuran tentang bagaimana seseorang berespon terhadap kesulitan.

Adapun faktor-faktor untuk meningkatkan Adversity Quotient seseorang adalah kinerja, bakat dan kemauan, kecerdasan, kesehatan dan karakter serta genetika, pendidikan dan keyakinan. Dalam faktor keyakinan adalah adanya keyakinan yang mendalam dan mantap terhadap sesuatu atau hal yang lebih besar terhadap dirinya sendiri. Di mana iman dalam keyakinan merupakan faktor yang sangat penting dalam harapan, tindakan, moralitas, kontribusi dan bagaimana kita memperlakukan sesama kita (Stoltz, 2000).

Salah satu cara untuk meningkatkan Adversity Quotient dalam faktor keyakinan adalah membaca al-Qur'an. Membaca alQur'an merupakan pekerjaan yang utama, yang mempunyai berbagai keistimewaan dan kelebihan dibandingkan dengan membaca bacaan yang lain. Al-Qur'an sendiri menurut menurut Shubhi Shaleh dalam kitabnya mabis fi ulum al-Qur'an, yang telah disepakati ahli bahasa, ahli kalam, ahli fiqih dan ushul fiqih. AlQur'an adalah firman Allah SWT yang berfungsi sebagai mu'jizat yang diturunkan kepada nabi Muhammad SAW yang tertulis dalam mushaf-mushaf yang diriwayatkan secara mutawatir dan membacanya merupakan ibadah (Lutfiah, 2010).

Membaca al-Qur'an sampai tahap memahami makna yang terkandung di dalam al-Qur'an, maka akan memperoleh ketenangan, karena di dalam al-Qur'an terdapat ayat-ayat yang sangat bermanfaat bagi manusia dalam menjalani hidup. Segala yang terdapat dalam al-Qur'an adalah petunjuk bagi kehidupan manusia di dunia maupun di akhirat kelak, jika seseorang sering membaca dan memahami al-Qur'an maka akan memperoleh banyak informasi penting mengenai segala hal, sehingga dalam menjalankan kehidupan di dunia seseorang tersebut akan lebih memiliki keyakinan terhadap pengetahuan, kemampuan dan penampilannya sendiri sesuai dengan yang terdapat dalam alQur'an (Pradika, 2014).

Menurut Khon (2007) seseorang yang membaca al-Qur'an mendapat pahala sepuluh kebaikan dan keberkahan dalam hidupnya bagaikan sebuah rumah yang dihuni oleh pemiliknya dan tersedia segala perabotan dan peralatan yang diperlukan. Demikianlah hati orang yang tidak membaca al-Qur'an, akan terjadi kekosongan jiwa dan membuat orang sesat dari jalan yang lurus. Oleh karena itu, Rasulullah SAW mendorong umat Islam untuk membaca al-Qur'an secara mudawamah (terus menerus, kontiniu), memahami makna dan mengamalkannya serta memedomani dalam kehidupan sehari-hari.

Membaca al-Qur'an bagi siswi asrama seharusnya sudah menjadi rutinitas yang harus dilaksanakan, dengan 
memperhatikan adab-adab membaca alQur'an yang ialah (Abidin, 1992): a.Disunatkan membaca al-Qur'an sesudah berwudhu, b.Disunatkan membaca alQur'an di tempat yang bersih, yang paling utama ialah di masjid, c. Disunatkan membaca al-Qur'an menghadap ke kiblat, membacanya dengan khusyu' dan tenang, d. Ketika membaca al-Qur'an mulut hendaknya bersih, e. Sebelum membaca alQur'an disunatkan membaca ta'awwudzsesudah itu baru membaca basmalah, f. Disunatkan membaca alQur'an denga tartil, yaitu dengan bacaan yang pelan-pelan dan tenang, g. Bagi orang yang sudah mengerti arti dan maksud ayatayat al-Qur'an, disunatkan membacanya dengan penuh perhatian dan pemikiran tentang ayat-ayat yang dibacanya dan maksudnya, h. Disunatkan membaca alQur'an dengan suara yang bagus lagi merdu asalkan tidak melanggar hukum bacaan al-Qur'an, i. Sedapat-dapatnya membaca al-Qur'an janganlah diputuskan hanya karena hendak berbicara dengan orang lain. Sehingga remaja yang tinggal di asrama memiliki ketangguhan dan mampu bertahan dalam menjalani rutinitas kehidupannya baik di lingkungan asrama, di sekolah, di rumah dan di lingkungan lainnya.

Menjalani pendidikan dan kehidupan di asrama tentu berbeda dengan menjalani pendidikan dan kehidupan di luar pesantren. Segala aktivitas belajar dan kehidupan sehari-hari dilakukan di dalam asrama. Siswi yang tinggal di asrama akan belajar melalui kehilangan orang tua atau orang yang dicintainya, kejadian-kejadian yang menyedihkan, penolakan dari teman sebaya, kritikan dari guru atau pembina asrama, aturan-aturan yang mengikat seluruh kegiatan dan lain sebagainya. Kejadian-kejadian ini membuat siswi tersebut terfokus pada bahaya yang dianggapnya mengancam dan semakin merasa tidak mampu menghindari bahaya.

Siswi yang memiliki masalah kurang percaya diri dan masalah ekonomi selalu menganggap dirinya inferior, buruk dan tidak disukai sehingga memandang masa depan mereka akan gagal dan suram. Siswi yang memiliki konflik dengan teman selalu menganggap dirinya sebagai biang kesalahan tidak berani untuk membela diri jika dia tidak bersalah.

Dalam melakukan sesuatu kegiatan tidak selamanya semuanya berjalan lancar, adakalanya dihadapkan pada kegagalan, hambatan dan kesulitan. Kesulitankesulitan menjalani pendidikan dan kehidupan di asrama yang belajar hidup mandiri, mengikuti segala aturan-aturan yang ada di asrama.

\section{E. SIMPULAN}

Pengaruh dari pemberian treatment berupa membaca al-Qur'an, di mana terdapat perbedaan antara pretest dan posttest kelompok eksperimen, yaitu terjadi peningkatan Adversity Quotient. Sedangkan pada kelompok kontrol yang tidak melakukan membaca al-Qur'an, menunjukkan tidak adanya perbedaan secara signifikan atau bahkan mengalami penurunan. Hal tersebut dapat disimpulkan bahwa adanya pengaruh membaca alQur'an terhadap Adversity Quotient pada kelompok eksperimen.

\section{SARAN}

Siswi yang telah mengikuti kegiatan membaca al-Qur'an hendaknya menerapkannya dalam rutinitas kesehariannya terus. Penelitiberharap kepada institusi pendidikan untuk berperan membantu mahasiswa dalam meningkatkan Adversity Quotient melalui membaca al-Qur'an.Peneliti juga berharap adanya peneliti-peneliti selanjutnya yang melakukan penelitian tentang Adversity Quotient dan membaca al-Qur'an.

\section{DAFTAR KEPUSTAKAAN}

Abidin, Zainal. (1992). Seluk Beluk alQur'an. Jakarta: PT Rineka Cipta. 
Anshori. (2013). Ulumul Qur'an: Kaidah Memahami Firman Tuhan. Jakarta: Rajawali Pers.

Chaplin, P. (2009). Kamus Lengkap Psikologi. Jakarta: Rajawali Pers.

Echols, J. M. \& Shadily, H. (2014). Kamus Inggris-Indonesia Edisi yang Diperbarui. Jakarta: PT Gramedia Pustaka.

Hurlock, E, B. (1993). Psikologi Perkembangan: Suatu Pendekatan Sepanjang Rentang Kehidupan Edisi ke-5. Jakarta: Erlangga.

Jalaluddin. (2011). Psikologi Agama Memahami Perilaku Keagamaan dengan Mengaplikasikan Prinsipprinsip Psikologi. Jakarta:Raja Grafindo Persada.

Khon, A.M. (2007). Pratikum Qira'at: Keanehan Bacaan al-Qur'an. Jakarta: Amzah.

Khon, A.M. (2011). Pratikum Qira'at: Keanehan Bacaan al-Qur'an Edisi Revisi. Jakarta: Amzah.

Latipun. (2006). Psikologi Ekperimen Edisi ke Dua. Malang: Universitas Muhammadiyah Malang.

Lutfiah, S \& Khalifah. (2010). Religiopsioneuroimunologi al-Qur'an (Studi Kolaborasi Terapi al-Qur'an dan Fungsi Otak dalam Menghadapi Stres. Buletin Psikologi: Fakultas Psikologi Universitas Gajah Mada ISSN:0854-7108 18(1), 19-28.

Mar'ati, R \& Chaer, M.T. (2016). Pengaruh Pembacaan dan Pemaknaan Ayat- ayat al-Qur'an Terhadap Penurunan Kecemasan pada Santriwati. Psikohumaniora: Jurnal Penelitian Psikologi. Volume 1 No. 1 hal. 30-48.

Nawawi, R.S. (2011). Kepribadian Qur'ani. Jakarta: Amzah.

Pedak, M. (2009). Qur'an for Gen (Mukjizat Terapi al-Qur'an untuk Hidup Sukses). Jakarta: Wahyumedia.

Pradika, F.M. (2014). Hubungan Antara Intensitas Membaca Ayat Suci alQur'an dengan Kepercayaan Diri pada Mentor Kegiatan Mentoring Universitas Muhammadiyah Surakarta. Fakultas Psikologi Universitas Surakarta. Skripsi tidak diterbitkan.

Sapuri, R. (2009). Psikologi Islam: Tuntunan Jiwa Manusia Modern. Jakarta: Rajawali Pers.

Stoltz, P. G. (2000). Adversity Quotient: Mengubah Hambatan Menjadi Peluang. Jakarta: PT Grasindo.

Sugiyono (2010). Metode Penelitian Kuantitatif, Kualitatif dan $R \& D$. Bandung: Alfabeta.

Utsman, N.M. (2005). Psikologi Islam dalam al-Qur'an (Terapi Qur'ani dalam Penyembuhan Gangguan Kejiwaan). Bandung: Pustaka Setia.

Zulaiha. S. (2014). Pengaruh Tadarus alQuran terhadap Kecerdasan Spiritual (Ikhlas) di SDIT MTA Gemolong Kabupaten Sragen. Naskah Publikasi. Fakultas Keguruan dan Ilmu Pendidikan Universitas Muhammadiyah Surabrata. 